\title{
Novel Rickettsia raoultii strain isolated and propagated from Austrian Dermacentor reticulatus ticks
}

\author{
Michiel Wijnveld ${ }^{1 *}$, Anna-Margarita Schötta ${ }^{1}$, Adriano Pintér $^{2}$, Hannes Stockinger $^{1}$ and Gerold Stanek ${ }^{1}$
}

\begin{abstract}
Background: Continuous culture of tick cell lines has proven a valuable asset in isolating and propagating several different vector-borne pathogens, making it possible to study these microorganisms under laboratory conditions and develop serological tests to benefit public health. We describe a method for effective, cost- and labor-efficient isolation and propagation of Rickettsia raoultii using generally available laboratory equipment and Rhipicephalus microplus cells, further demonstrating the usefulness of continuous tick cell lines. $R$. raoultii is one of the causative agents of tick-borne lymphadenopathy (TIBOLA) and is, together with its vector Dermacentor reticulatus, emerging in novel regions of Europe, giving rise to an increased threat to general public health.

Methods: Dermacentor reticulatus ticks were collected in the Donau-Auen (Lobau) national park in Vienna, Austria. The hemolymph of ten collected ticks was screened by PCR-reverse line blot for the presence of rickettsial DNA. A single tick tested positive for $R$. raoultii DNA and was used to infect Rhipicephalus microplus BME/CTVM2 cells.

Results: Sixty-five days after infection of the tick-cell line with an extract from a $R$. raoultii-infected tick, we observed intracellular bacteria in the cultured cells. On the basis of microscopy we suspected that the intracellular bacteria were a species of Rickettsia; this was confirmed by several PCRs targeting different genes. Subsequent sequencing showed 99-100 \% identity with $R$. raoultii. Cryopreservation and resuscitation of $R$. raoultii was successful. After 28 days identical intracellular bacteria were microscopically observed.

Conclusions: $R$. raoultii was successfully isolated and propagated from D. reticulatus ticks using R. microplus BME/ CTVM2 cells. The isolated strain shows significant molecular variation compared to currently known sequences. Furthermore we show for the first time the successful cryopreservation and resuscitation of $R$. raoultii.
\end{abstract}

Keywords: Rickettsia raoultii, Dermacentor reticulatus, Austria, BME/CTVM2, Isolation, Culture

\section{Background}

Dermacentor reticulatus, also known as the ornate dog tick, is a dark-colored tick with a light-colored pattern on its scutum (Fig. 1). Recorded hosts of D. reticulatus include wild and domesticated carnivores, sheep, cattle, and horses [1,2]; human infestation is not uncommon [2-4].

The typical habitats of this tick are open areas such as meadows, dune valleys, and floodplains [2] with a high degree of humidity [1]; this is in contrast to Ixodes

\footnotetext{
* Correspondence: michiel.wijnveld@meduniwien.ac.at

${ }^{1}$ Institute for Hygiene and Applied Immunology, Center for Pathophysiology, Infectiology and Immunology, Medical University of Vienna, Kinderspitalgasse 15, 1090 Vienna, Austria

Full list of author information is available at the end of the article
}

ricinus, which prefers greater shelter within deciduous and coniferous woodland areas [1]. In addition, the seasonal activity of $D$. reticulatus differs from that of most other European tick species, with larvae and nymphs being active in spring and summer, followed by adult activity starting in early autumn going late into winter, with a short pause when conditions become too harsh, activity then resuming thereafter leading in several geographical locations to an additional activity peak in spring $[1,2,5-7]$. This pattern of activity results in $D$. reticulatus being active for nearly the whole year. Furthermore, it has become apparent in recent years that $D$. reticulatus is spreading to new areas, increasing its foothold within Europe [2, 8-12] and increasing 


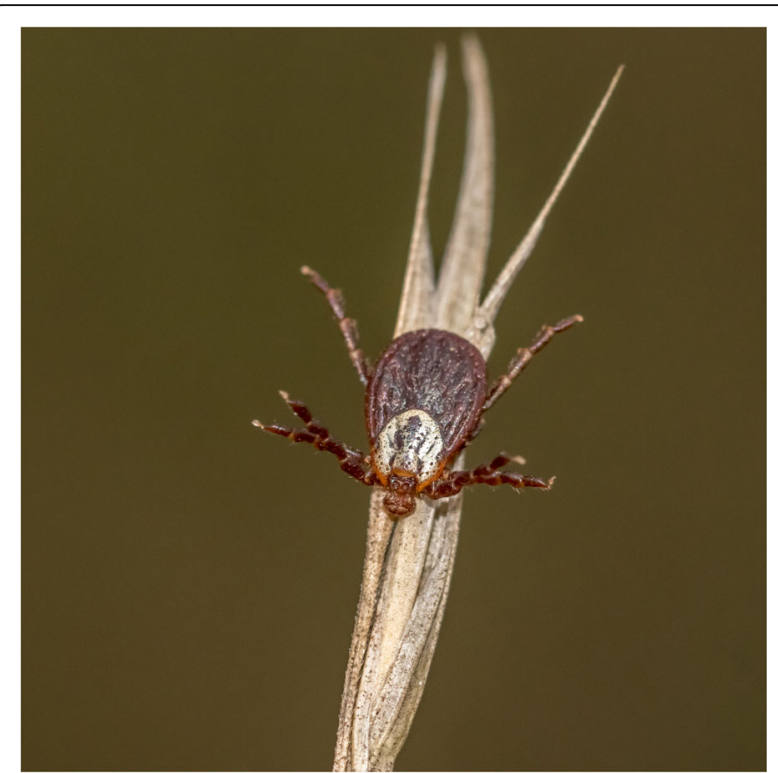

Fig. 1 Female Dermacentor reticulatus tick in a questing position

exposure of humans and animals to this tick species and its transmitted pathogens. Thus, the expansion of $D$. reticulatus into new territories, with seasonal activity in northern regions unlike that of I. ricinus, and the possible transmission of zoonotic pathogens pose a serious risk. Public awareness of the dangers of D. reticulatus bites needs to increase.

Among the pathogens transmitted by $D$. reticulatus, Rickettsia raoultii has a primary position, with infection rates up to $20 \%$ in questing ticks [13], in some areas reaching even higher rates $(50-58 \%)[14,15]$. Rickettsia raoultii belongs to the spotted fever group Rickettsia and is one of the causative agents of tick-borne lymphadenopathy (TIBOLA), which is also known as Dermacentor-borne necrosis erythema and lymphadenopathy (DEBONEL) in humans [3]. Symptoms include an inoculation eschar at the tick-bite location, (cervical) lymphadenopathy, (high) fever, malaise, and headaches [16]. As its vector expands to new foci, with recent novel detections in several countries of Europe, $R$. raoultii presents as an emerging disease-causing agent [17-20].

The increasing medical relevance of $R$. raoultii in Europe requires further studies of this organism. Here we describe a method for its isolation and propagation using generally available laboratory equipment and the low-maintenance embryo-derived tick cell line BME/ CTVM2 derived from Rhipicephalus microplus [21].

\section{Methods}

\section{Ticks}

Dermacentor reticulatus ticks were visualized and collected directly from the vegetation in the Donau-Auen (Lobau) national park in Vienna, Austria, in October 2015, and were morphologically identified using standard identification keys [1]. Ten of the collected ticks were selected randomly to screen for the presence of Rickettsia raoultii DNA.

\section{DNA extraction from hemolymph of single tick legs}

A single leg was cut from each of the ten selected ticks; the ticks were kept alive in individual collection tubes stored at $4{ }^{\circ} \mathrm{C}$ until further use. DNA was extracted from individual tick legs using the NucleoSpin Tissue XS kit (Macherey-Nagel, Düren, Germany) according to the manufacturer's instructions and with a total elution volume of $15 \mu l$.

\section{PCR-reverse line blot}

Rickettsial DNA was detected using PCR followed by reverse line blot (RLB) hybridization targeting the Rickettsia spp. 16S rRNA gene, as previously described [22, 23]. Rickettsia genus-specific and $R$. conorii and $R$. raoultii species-specific probes described by Christova et al. and Nijhof et al. were used [23, 24]. Briefly, the PCR reaction mix (total reaction volume $25 \mu \mathrm{l}$ ) contained $5 \mu \mathrm{l}(5 \times)$ Phire reaction buffer, $200 \mathrm{nmol} / \mathrm{l}$ of each dNTP (Solis Biodyne, Tartu, Estonia), $400 \mathrm{nmol} / \mathrm{l}$ of each primer (Rick-F1 and Rick-R2 as in Table 1), 0.125 units Phire Hot Start II DNA Polymerase (Thermo Scientific, Vienna, Austria), $2.5 \mu \mathrm{l}$ template DNA [DNA extracts, R. conorii positive control (Ingenetix, Vienna, Austria), and no-template control, respectively], and PCR-grade water (Sigma-Aldrich, Vienna, Austria). A C1000 Touch Thermal Cycler (Bio-Rad, Vienna, Austria) was used for the PCR reactions, starting with a touch-down protocol in which the annealing temperature was lowered by $1^{\circ}$ per cycle for the initial 10 cycles $\left(98^{\circ} \mathrm{C}\right.$ for $5 \mathrm{~s}, 67^{\circ} \mathrm{C}$ to $57{ }^{\circ} \mathrm{C}$ for $5 \mathrm{~s}$, and $72{ }^{\circ} \mathrm{C}$ for $10 \mathrm{~s}$ ) followed by 45 cycles with a fixed annealing temperature $\left(98{ }^{\circ} \mathrm{C}\right.$ for $5 \mathrm{~s}, 57^{\circ} \mathrm{C}$ for $5 \mathrm{~s}$, and $72{ }^{\circ} \mathrm{C}$ for $10 \mathrm{~s}$ ). The initial touch-down cycles were used to increase the specificity of the PCR reactions. All PCR products were used in the RLB assay as described previously [25] and were visualized using the ChemiDoc Touch Imaging System (Bio-Rad). The RLB membrane was exposed for $10 \mathrm{~min}$ to detect the chemiluminescence of the bound PCR products.

\section{Tick surface disinfection and homogenization}

A single tick from the ten that were tested gave a positive result for presence of $R$. raoultii DNA. The surface of the tick was disinfected using thiomersal, benzalkonium chloride and $70 \%$ ethanol solutions followed by 2 rinses in sterile demineralized water, as described by Bell-Sakyi [26]. After disinfection, the tick was cut with a sterile scalpel and homogenized in complete L-15 cell culture medium (Leibovitz's L-15 medium, Gibco, Thermofisher Scientific, Vienna, Austria) [27] using a 
Table 1 Primers used during this study

\begin{tabular}{|c|c|c|c|c|}
\hline Name & Sequence $\left(5^{\prime}-3^{\prime}\right)$ & Annealing temperature $\left({ }^{\circ} \mathrm{C}\right)$ & Target & Reference \\
\hline Rick-F1 & GAACGCTATCGGTATGCTTAACACA & $67-57^{\mathrm{a}}$ & $16 \mathrm{~S}$ ribosomal RNA gene & [23] \\
\hline Rick-R2 & CATCACTCACTCGGTATTGCTGGA & & & \\
\hline $\mathrm{RCK} / 23-5-\mathrm{F}$ & GATAGGTCRGRTGTGGAAGCAC & $65-55^{\mathrm{a}}$ & 23S-5S ribosomal RNA intergenic spacer & [29] \\
\hline $\mathrm{RCK} / 23-5-\mathrm{R}$ & TCGGGAYGGGATCGTGTGTTTC & & & \\
\hline D1f & ATGAGTAAAGACGGTAACCT & 60 & sca4 & [37] \\
\hline D928r & AAGCTATTGCGTCATCTCCG & & & \\
\hline $190-70$ & ATGGCGAATATTTCTCCAAAA & 60 & ompA & [38] \\
\hline 190-701 & GTTCCGTTAATGGCAGCATCT & & & \\
\hline $120-2788$ & AAACAATAATCAAGGTACTGT & 60 & $o m p B$ & [39] \\
\hline $120-3599$ & TACTTCCGGTTACAGCAAAGT & & & \\
\hline CS-78 & GCAAGTATCGGTGAGGATGTAAT & 60 & gltA & [40] \\
\hline CS-323 & GCTTCCTTAAAATTCAATAAATCAGGAT & & & \\
\hline
\end{tabular}

a Touch down PCR protocol decreasing annealing temperature by $1{ }^{\circ} \mathrm{C}$ per cycle during the first 10 cycles

100-1,000 $\mu \mathrm{l}$ Radnoti Micro Homogenizer (Radnoti, Dublin, Ireland). The cell suspension in the homogenate was separated from tick debris using a $1 \mathrm{ml}$ Micro-Fine ${ }^{\mathrm{Tm}}$ insulin syringe, 29 gauge (BD, Oxford, UK). Portions $(100 \mu \mathrm{l})$ of the obtained cell suspension were transferred directly into two individual tick cell cultures; a third tick cell culture was maintained as a negative control. All 3 cell cultures originated from a single parental culture to eliminate cell variation. All steps were performed under sterile conditions in a class II laminar flow cabinet.

\section{Culture of tick cell line}

The tick cell line BME/CTVM2 (The Tick Cell Biobank, Pirbright, UK) originating from $R$. microplus [21] was maintained, as previously described [27], at $28{ }^{\circ} \mathrm{C}$ in flatsided cell culture tubes (Nunc, Thermofisher Scientific, Vienna, Austria) containing $2 \mathrm{ml} \mathrm{L}-15$ medium supplemented with $2 \mathrm{mmol} / \mathrm{L}$ L-glutamine (HyClone, GE Healthcare Life sciences, Vienna, Austria), 10 \% tryptose phosphate broth (Gibco, Thermofisher Scientific, Vienna, Austria), $20 \%$ fetal calf serum (Sigma Aldrich, Vienna, Austria), and $100 \mathrm{U} / \mathrm{ml}$ penicillin and $100 \mu \mathrm{g} / \mathrm{ml}$ streptomycin (Pen Strep, Gibco). The medium was changed weekly, when samples of the infected and the negativecontrol cell cultures were taken for cytological analysis.

\section{Staining of cytocentrifuge smears}

After the weekly change of medium, tick cells were resuspended using a glass Pasteur pipette. From this suspension $\approx 100 \mu \mathrm{l}$ was used to prepare cytocentrifuge smears using a Basic Cytology Rotor in a Rotofix 32A centrifuge (Hettich Lab Technology, Tuttlingen, Germany) with a single cytology funnel (Biomedical Polymers, Gardner, MA, USA). Centrifugation conditions were 700x $g$ for $5 \mathrm{~min}$. The obtained smears were stained with
Giménez stain [28]. Stained smears were analyzed microscopically for the presence of Rickettsia-like intracellular bacteria.

DNA extraction of tick cell cultures, PCR and sequencing

After observing Rickettsia-like intracellular bacteria, DNA was extracted from $200 \mu \mathrm{l}$ cell suspension using the NucleoSpin Tissue kit (Macherey-Nagel, Düren, Germany) according to the manufacturer's guidelines. The presence and identity of suspected rickettsial bacteria was confirmed using several PCRs targeting different genes and regions: gltA, ompA, ompB, sca4, 16S ribosomal RNA, and the 23S-5S ribosomal RNA intergenic spacer (see Table 1 for primers and annealing temperatures). Phire Hot Start II DNA Polymerase (0.5 units) and a reduced volume of PCR-grade water were used. The concentration of the other components in the PCR mix were as described above. PCR products were analyzed using $1 \%$ agarose gel electrophoresis, loading the full $25 \mu \mathrm{l}$ of PCR product onto the gel. Subsequently, fragments of interest were extracted from the gel using the QIAquick gel extraction kit (Qiagen, Hilden, Germany), following the protocol provided. All obtained PCR fragments were sent to Microsynth (Balgach, Switzerland) for bidirectional sequencing, and consensus sequences have been submitted to GenBank (http:// www.ncbi.nlm.nih.gov/genbank/) under accession numbers KX500092-KX500097.

\section{PCR-RLB detection of $R$. raoultii strain Jongejan}

To detect the isolated $R$. raoultii strain, a new strainspecific probe was designed ( $R$. raoultii strain Jongejan probe: 5'-TCA ACT AAT AAA TTT GCT GAG TA-3') to be used in a PCR-RLB assay targeting the 23S-5S ribosomal RNA intergenic spacer [29]. The procedure was performed as described above, with some minor 
modifications. Briefly, a touch-down protocol was used in the PCR $\left(65{ }^{\circ} \mathrm{C}\right.$ going down to $55{ }^{\circ} \mathrm{C}$ during the first ten cycles) and in the RLB the primers and probes were as described by Jado et al. [29], together with the newly designed strain-specific probe.

\section{Cryopreservation and resuscitation of Rickettsia raoultii}

Combining and modifying previously published methods [30, 31], cryopreservation and resuscitation was carried out as follows: infected cell suspensions were transferred to $2 \mathrm{ml}$ safe-lock microcentrifuge tubes (Eppendorf AG, Hamburg, Germany), and chilled on ice before centrifugation. Centrifugation was carried out at $17,000 \times \mathrm{g}$ for $10 \mathrm{~min}$ at $4{ }^{\circ} \mathrm{C}$. After discarding the supernatant, the pellet was resuspended using half the original volume of fresh complete L-15 medium. After resuspension, complete L-15 medium supplemented with $20 \%$ dimethylsulfoxide (DMSO) was added until $100 \%$ of the original volume was reached, obtaining a final DMSO concentration of $10 \%$. All components were used prechilled at $4{ }^{\circ} \mathrm{C}$. Aliquots $(100 \mu \mathrm{l})$ were prepared in CryoTubes (Nunc, Thermofisher Scientific, Vienna, Austria) and flash frozen in liquid nitrogen; aliquots were stored either at $-80{ }^{\circ} \mathrm{C}$ or in liquid nitrogen. Resuscitation was carried out by rapidly thawing the cell suspensions in a water bath at $37{ }^{\circ} \mathrm{C}$, adding $1.9 \mathrm{ml}$ complete $\mathrm{L}-15$ medium, and transferring the suspension to $2 \mathrm{ml}$ safelock microcentrifuge tubes. Subsequently, the cell suspensions were centrifuged at $17,000 \times \mathrm{g}$ for $10 \mathrm{~min}$ at $4^{\circ}$ $\mathrm{C}$, supernatant discarded and the pellet was resuspended in $100 \mu \mathrm{l}$ complete $\mathrm{L}-15$ medium. The cell suspension was directly used to inoculate uninfected BME/CTVM2 tick cells.

\section{Results}

We incubated cell suspensions of $D$. reticulatus with the tick cell line $R$. microplus BME/CTVM2, and after 65 days we observed intracellular bacteria in the cultured cells (Fig. 2). The negative control culture remained free of (intracellular) bacteria. On the basis of the microscopy we suspected that the intracellular bacteria were a species of Rickettsia; this was confirmed in several PCRs targeting different genes. PCR fragments sent for sequencing showed 99-100 \% (KX500092-KX500097) identity with $R$. raoultii sequences available in the NCBI GenBank database (Table 2). Of note, we observed a 60 bp deletion when the 23S-5S ribosomal RNA intergenic spacer fragment was compared with the full genome sequence available for $R$. raoultii strain Khabarovsk (CP010969.1) (Fig. 3). A strain-specific RLB probe was designed to span this 60 bp deletion (Fig. 3). Furthermore, the obtained sequence of the sca4 gene showed insertion of a single nucleotide that caused a frameshift resulting in a pseudogene. The isolated strain showed high identity

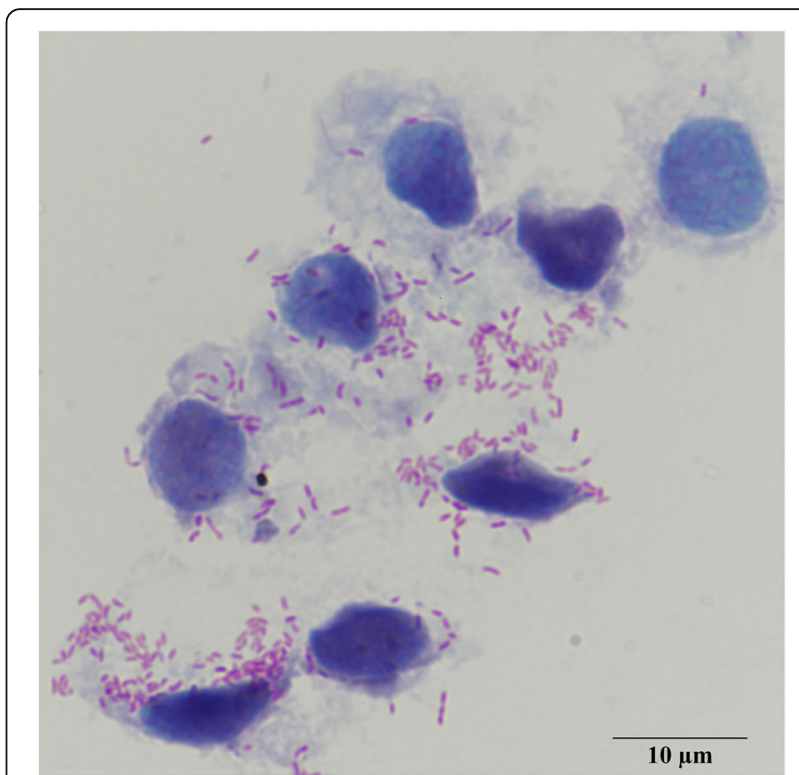

Fig. 2 Infected tick cells, Giménez stain in which the bacteria are stained red/pink and the host cells blue

with $R$. raoultii and we named this strain $R$. raoultii strain Jongejan.

Viability of the newly isolated strain was assessed by (sub)inoculating either $100 \mu \mathrm{l}$ cell suspension or $100 \mu \mathrm{l}$ medium (taken without disturbing the cell layer). Both methods successfully infected BME/CTVM2 cells: identical intracellular bacteria were present in cytocentrifuge smears of these newly infected cultures within 14 to 21 days. We also used a PCR-RLB assay targeting the 23S-5S ribosomal RNA intergenic spacer and the newly designed strain-specific probe to confirm the successful subculture of $R$. raoultii strain Jongejan.

Cryopreservation and resuscitation of $R$. raoultii strain Jongejan proved successful as both, $80{ }^{\circ} \mathrm{C}$ and in liquid nitrogen stored cell suspensions successfully infected BME/CTVM2 cells; after 28 days identical intracellular bacteria were observed while analyzing the cytocentrifuge smears.

\section{Discussion}

Previously, the centrifugation-shell vial technique described by Marrero \& Raoult [32] was used to isolate $R$. raoultii in VERO and L929 mammalian cell line cultures [33]. However, the method required specialized equipment and more regular maintenance of the cell lines, making it laborious and less cost efficient. More recently, tick cells have been used to isolate $R$. raoultii, e.g. embryo-derived culture cell lines originating from $R$. sanguineus (RLM-RSE) [34] or embryo-derived primary cell lines of $D$. reticulatus [27]. After an initial cultivation period of 14-16 months in primary D. reticulatus cell lines, propagation of $R$. raoultii was successful in a 
Table 2 Relationship of $R$. raoultii strain Jongejan with available NCBI sequences

\begin{tabular}{lllll}
\hline Target & Accession no. & Size (bp) & Identity (\%) & Closest related R. raoultii sequence \\
\hline 16S ribosomal RNA & KX500096 & 252 & 99 & KJ410261.1 \\
23S-5S ribosomal RNA intergenic spacer & KX500097 & 157 & $100^{\mathrm{b}}$ & CP010969.1 \\
sca4 & KX500095 & 802 & $100^{\mathrm{c}}$ & DQ365807.1 \\
ompA & KX500093 & 513 & 100 & AH009131.2 \\
ompB & KX500094 & 710 & 100 & KU310593.1 \\
gltA & KX500092 & 259 & 100 & KU310589.1 \\
\hline
\end{tabular}

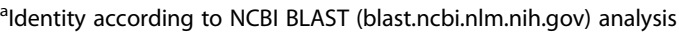

${ }^{b}$ Contains a 60 base-pair deletion when compared with the reference genome (CP010969.1)

'Single nucleotide insertion results into a pseudogene

number of tick cell lines originating from $D$. albipictus, $D$. nitens, and $R$. microplus [27], using the same $R$. microplus cell line as used in our study. It is possible that the initial cultivation period of $14-16$ months aided the adjustment of $R$. raoultii towards the laboratory cultivation conditions, making subcultivations more likely to succeed. We show for the first time the capability of the $R$. microplus cell line BME/CTVM2 as initial isolation host for $R$. raoultii. Successful cryopreservation and resuscitation of $R$. raoultii has, to the best of our knowledge, not been documented before.

The sequences obtained from the newly named $R$. raoultii strain Jongejan showed differences within the 23S-5S ribosomal RNA intergenic spacer and the sca4 gene when compared with the full genome sequence of strain Khabarovsk (CP010969.1). The 23S-5S spacer is non-coding, therefore selective pressure is low and mutations within the spacer can occur frequently. Due to the non-coding nature of the spacer, the deletion most likely does not influence the behavior or the pathogenicity of the bacteria. The sca4 gene, together with the ompA and $о т p B$ genes, are part of a group coding the cell surface antigen proteins (immunodominant surface protein antigens) forming the outer cell surface of Rickettsia bacteria [35]. In patients, the immune response towards these proteins is strong [36], and the proteins are under positive selection pressure to evade the immune system, which results in high variation within these genes [35]. Furthermore, the single nucleotide insertion is also present within another published sequence of $R$. raoultii strain Marne (DQ365807.1); Strain Jongejan varies to strain Marne within the $16 \mathrm{~s}$ rRNA and $o m p B$ genes by $1 \%$ (identity $99 \%$ ). The specific phenotypical change due to the sca4 mutation needs to be further studied in order to assess the bacterial behavior and possible change to the pathogenicity of this strain. Considering the distinct molecular characteristics of strain Jongejan, we designed a specific probe for its detection in field specimens, thus enabling screening on a geographical basis and determination of the distribution of this strain.

Together with previous work [21, 27, 34], our study shows that tick cell lines are an aid in the isolation of tick-borne microorganisms, thus benefiting medicine and research. The use of such cell lines provides a platform for development of serological tests for screening patients and facilitates further study of the organisms. Future research should assess the capability of tick cell cultures in isolation of Rickettsia species from clinical samples. Our results also demonstrate that tick cell lines might be useful in culturing tick-borne pathogens that are currently uncultivable, such as Candidatus Neoehrlichia mikurensis. Moreover, geographical screening of $D$. marginatus and D. reticulatus would be beneficial in investigation of the distribution of different $R$. raoultii strains, both locally in Austria and in larger areas within Eurasia.

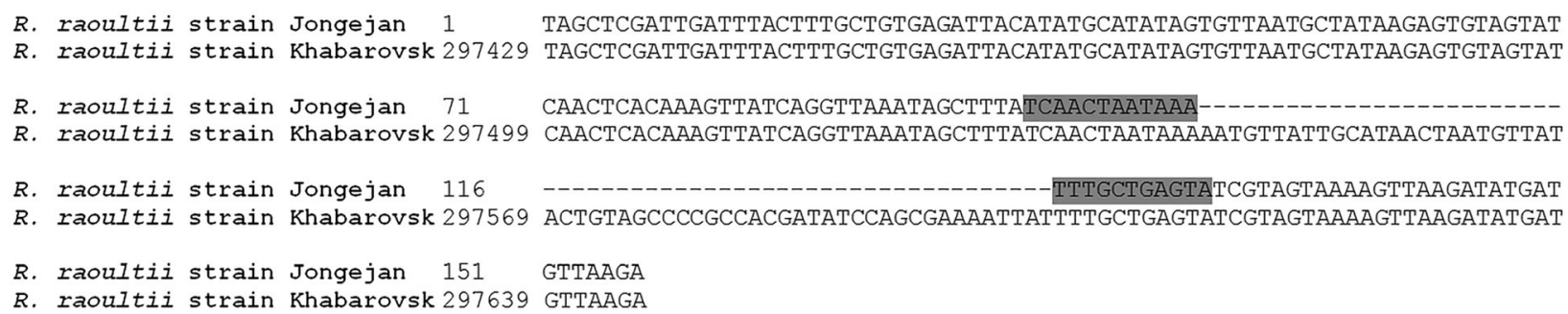

Fig. 3 Alignment, obtained with MEGA version 6, of the 23S-5S ribosomal RNA intergenic spacer of R. raoultii strain Jongejan in comparison with $R$. raoultii strain Khabarovsk (CP010969.1), showing a 60 bp deletion in the intergenic spacer region. The $R$. raoultii strain Jongejan-specific probe sequence is highlighted in grey, spanning this deletion 


\section{Conclusions}

During our study $R$. raoultii has been successfully isolated and propagated. Genetic analysis of the isolated strain revealed significant differences compared to the currently available data in the NCBI GenBank database. These molecular variations might lead to differences in phenotype and the behavior of the microorganism, potentially increasing the risk for human health. Furthermore our study shows for the first time the successful cryopreservation and resuscitation of $R$. raoultii.

\section{Abbreviations \\ DEBONEL: Dermacentor-borne necrosis erythema and lymphadenopathy; DMSO: Dimethylsulfoxide; RLB: Reverse line blot; TIBOLA: Tick-borne lymphadenopathy}

\section{Acknowledgements}

Not applicable.

\section{Funding}

This research received no specific grant from any funding agency in the public, commercial, or not-for-profit sectors.

\section{Availability of data and materials}

All obtained DNA sequences have been submitted to the GenBank (http:// www.ncbi.nlm.nih.gov/genbank/) under accession numbers KX500092KX500097.

\section{Author's contributions}

MW designed the study, carried out the experiments together with A.-M.S., and wrote the manuscript. AP provided valuable insights in the isolation methods of Rickettsia spp. and confirmed microscopy analysis. HS helped improve the manuscript with valued comments. GS provided materials and supervised the study. All authors read and approved the final version of the manuscript.

\section{Competing interests}

The authors declare that they have no competing interests.

\section{Consent for publication}

Not applicable.

\section{Ethics approval and consent to participate}

Not applicable.

\author{
Author details \\ ${ }^{1}$ Institute for Hygiene and Applied Immunology, Center for Pathophysiology, \\ Infectiology and Immunology, Medical University of Vienna, Kinderspitalgasse \\ 15, 1090 Vienna, Austria. ${ }^{2}$ Public Health Department, Superintendência de \\ Controle de Endemias, Rua Paula Sousa, 166 - Luz - 01027-000, São Paulo, \\ São Paulo, Brazil.
}

Received: 13 September 2016 Accepted: 24 October 2016 Published online: 03 November 2016

\section{References}

1. Estrada-Peña A, Bouattour A, Camicas J-L, Walker AR. Ticks of domestic animals in the Mediterranean region: A guide to identification of species. Zaragoza, Spain: University of Zaragoza; 2004.

2. Jongejan F, Ringenier M, Putting M, Berger L, Burgers S, Kortekaas R, et al. Novel foci of Dermacentor reticulatus ticks infected with Babesia canis and Babesia caballi in the Netherlands and in Belgium. Parasit Vectors. 2015:8:1-10.

3. Parola P, Rovery C, Rolain JM, Brouqui P, Davoust B, Raoult D. Rickettsia slovaca and $R$. raoultii in tick-borne rickettsioses. Emerg Infect Dis. 2009;15:1105-8.
4. Földvári G, Rigó K, Lakos A. Transmission of Rickettsia slovaca and Rickettsia raoultii by male Dermacentor marginatus and Dermacentor reticulatus ticks to humans. Diagn Microbiol Infect Dis. 2013;76:387-9.

5. Randolph SE, Miklisová D, Lysy J, Rogers DJ, Labuda M. Incidence from coincidence: patterns of tick infestations on rodents facilitate transmission of tick-borne encephalitis virus. Parasitology. 1999;118(Pt 2(July 2015)):177-86.

6. Duscher GG, Feiler A, Leschnik M, Joachim A. Seasonal and spatial distribution of ixodid tick species feeding on naturally infested dogs from Eastern Austria and the influence of acaricides/repellents on these parameters. Parasit Vectors. 2013;6:76.

7. Földvári G, Farkas R. Ixodid tick species attaching to dogs in Hungary. Vet Parasitol. 2005;129:125-31.

8. Hofmeester TR, van der Lei P-B, Docters van Leeuwen A, Sprong H, van Wieren SE. New foci of Haemaphysalis punctata and Dermacentor reticulatus in the Netherlands. Ticks Tick Borne Dis. 2015;7:10-3.

9. Dautel H, Dippel C, Oehme R, Hartelt K, Schettler E. Evidence for an increased geographical distribution of Dermacentor reticulatus in Germany and detection of Rickettsia sp. RpA4. Int J Med Microbiol. 2006;296 Suppl 1:149-56.

10. Kiewra D, Czulowska A. Evidence for an increased distribution range of Dermacentor reticulatus in south-west Poland. Exp Appl Acarol. 2013;59:501-6.

11. Široký P, Kubelová M, Bednář M, Modrý D, Hubálek Z, Tkadlec E. The distribution and spreading pattern of Dermacentor reticulatus over its threshold area in the Czech Republic - How much is range of this vector expanding? Vet Parasitol. 2011;183:130-5.

12. Bullová E, Lukáň M, Stanko M, Pet́ko B. Spatial distribution of Dermacentor reticulatus tick in Slovakia in the beginning of the 21st century. Vet Parasitol. 2009;165:357-60.

13. Reye AL, Stegniy V, Mishaeva NP, Velhin S, Hübschen JM, Ignatyev G, Muller CP. Prevalence of tick-borne pathogens in Ixodes ricinus and Dermacentor reticulatus ticks from different geographical locations in Belarus. PLoS One. 2013;8, e54476.

14. Wójcik-Fatla A, Cisak E, Zajac V, Sroka J, Sawczyn A, Dutkiewicz J. Study on tick-borne rickettsiae in eastern Poland. I. Prevalence in Dermacentor reticulatus (Acari: Amblyommidae). Ann Agric Environ Med. 2013;20:276-9.

15. Szekeres S, Docters van Leeuwen A, Rigó K, Jablonszky M, Majoros G, Sprong H, Földvári G. Prevalence and diversity of human pathogenic rickettsiae in urban versus rural habitats, Hungary. Exp Appl Acarol. 2015;68: 223-6.

16. Rieg S, Schmoldt S, Theilacker C, de With K, Wölfel S, Kern WV, Dobler G. Tick-borne lymphadenopathy (TIBOLA) acquired in Southwestern Germany. BMC Infect Dis. 2011;11:167.

17. Boldiš V, Kocianová E, Štrus J, Tušek-Žnidarič M, Sparagano OAE, Štefanidesová K, Špitalská E. Rickettsial agents in Slovakian ticks (Acarina, Ixodidae) and their ability to grow in Vero and L929 cell lines. Ann N Y Acad Sci. 2008;1149:281-5.

18. Duscher GG, Hodžić A, Weiler M, Vaux AGCC, Rudolf I, Sixl W, et al. First report of Rickettsia raoultii in field collected Dermacentor reticulatus ticks from Austria. Ticks Tick Borne Dis. 2016;7(5):720-2.

19. Radzijevskaja J, Paulauskas A, Aleksandraviciene A, Jonauskaite I, Stanko M, Karbowiak G, Petko B. New records of spotted fever group rickettsiae in Baltic region. Microbes Infect. 2015;17:874-8.

20. Hodžić A, Fuehrer H-P, Duscher GG. First molecular evidence of zoonotic bacteria in ticks in Bosnia and Herzegovina. Transbound Emerg Dis. 2016. In press.

21. Bell-Sakyi L. Ehrlichia ruminantium grows in cell lines from four ixodid tick genera. J Comp Pathol. 2004;130:285-93.

22. Giangaspero A, Marangi M, Papini R, Paoletti B, Wijnveld M, Jongejan F. Theileria sp. OT3 and other tick-borne pathogens in sheep and ticks in Italy: Molecular characterization and phylogeny. Ticks Tick Borne Dis. 2015;6:75-83.

23. Nijhof AM, Bodaan C, Postigo M, Nieuwenhuijs H, Opsteegh M, Franssen L, et al. Ticks and associated pathogens collected from domestic animals in the Netherlands. Vector Borne Zoonotic Dis. 2007;7:585-95.

24. Christova I, Van De Pol J, Yazar S, Velo E, Schouls L. Identification of Borrelia burgdorferi sensu lato, Anaplasma and Ehrlichia species, and spotted fever group Rickettsiae in ticks from Southeastern Europe. Eur J Clin Microbiol Infect Dis. 2003;22:535-42.

25. Lorusso V, Wijnveld M, Majekodunmi AO, Dongkum C, Fajinmi A, Dogo AG, et al. Tick-borne pathogens of zoonotic and veterinary importance in Nigerian cattle. Parasit Vectors. 2016;9:217. 
26. Bell-Sakyi L. Continuous cell lines from the tick Hyalomma anatolicum anatolicum. J Parasitol. 1991;77:1006-8.

27. Alberdi MP, Nijhof AM, Jongejan F, Bell-Sakyi L. Tick cell culture isolation and growth of Rickettsia raoultii from Dutch Dermacentor reticulatus ticks. Ticks Tick Borne Dis. 2012;3:349-54.

28. Gimenez DF. Staining rickettsiae in yolk-sac cultures. Stain Technol. 1964:39:135-40

29. Jado I, Escudero R. Molecular method for identification of Rickettsia species in clinical and environmental samples. J Clin Microbiol. 2006;44:4572-6.

30. Lallinger G, Zweygarth E, Bell-Sakyi L, Passos LM. Cold storage and cryopreservation of tick cell lines. Parasit Vectors. 2010;3:37.

31. Nicole C. Ammerman MB-S, Azad AF. Laboratory maintenance of Rickettsia rickettsii. Curr Protoc Microbiol. 2008;Chapter 3:Unit 3A.5. doi:10.1002/ 9780471729259.mc03a05s11.

32. Marrero M, Raoult D. Centrifugation-shell vial technique for rapid detection of Mediterranean spotted fever Rickettsia in blood culture. Am J Trop Med Hyg. 1989:40:197-9.

33. Mediannikov O, Matsumoto K, Samoylenko I, Drancourt M, Roux V, Rydkina E, et al. Rickettsia raoultii sp. nov., a spotted fever group Rickettsia associated with Dermacentor ticks in Europe and Russia. Int I Syst Evol Microbiol. 2008;58:1635-9.

34. Santibáñez S, Portillo A, Palomar AM, Bell-Sakyi L, Romero L, Oteo JA. Isolation and maintenance of Rickettsia raoultii in a Rhipicephalus sanguineus tick cell line. Microbes Infect. 2015;17:866-9.

35. Blanc G, Ngwamidiba M, Ogata H, Fournier PE, Claverie JM, Raoult D. Molecular evolution of Rickettsia surface antigens: Evidence of positive selection. Mol Biol Evol. 2005;22:2073-83.

36. Teysseire N, Raoult D. Comparison of western immunoblotting and microimmunofluorescence for diagnosis of Mediterranean spotted fever. J Clin Microbiol. 1992;30:455-60.

37. Sekeyova Z, Roux V, Raoult D. Phylogeny of Rickettsia spp. inferred by comparing sequences of "gene D", which encodes an intracytoplasmic protein. Int J Syst Evol Microbiol. 2001;51(Pt 4):1353-60.

38. Fournier $P$, Roux $V$, Raoult $D$. Phylogenetic analysis of spotted fever group rickettsiae by study of the outer surface protein rOmpA. Int I Syst Bacteriol. 1998;48 Pt 3:839-49.

39. Roux V, Raoult D. Phylogenetic analysis of members of the genus Rickettsia using the gene encoding the outer-membrane protein $\mathrm{rOmpB}$ (ompB). Int J Syst Evol Microbiol. 2000:50(Pt 4):1449-55.

40. Labruna MB, Whitworth T, Horta MC, Bouyer DH, McBride JW, Pinter A, et al. Rickettsia species infecting Amblyomma cooperi ticks from an area in the state of Sao Paulo, Brazil, where Brazilian spotted fever is endemic. J Clin Microbiol. 2004:42:90-8.

\section{Submit your next manuscript to BioMed Central and we will help you at every step:}

- We accept pre-submission inquiries

- Our selector tool helps you to find the most relevant journal

- We provide round the clock customer support

- Convenient online submission

- Thorough peer review

- Inclusion in PubMed and all major indexing services

- Maximum visibility for your research

Submit your manuscript at www.biomedcentral.com/submit

C) Biomed Central 